\title{
Audience Competency in Romans and Paul's Flexible Use of Scripture
}

\author{
B. J. Oropeza
}

\section{check for}

updates

Citation: Oropeza, B. J. 2021 Audience Competency in Romans and Paul's Flexible Use of Scripture. Religions 12: 916. https://doi.org/ $10.3390 /$ rel12110916

Academic Editor: Joel B. Green

Received: 19 July 2021

Accepted: 15 October 2021

Published: 21 October 2021

Publisher's Note: MDPI stays neutral with regard to jurisdictional claims in published maps and institutional affiliations.

Copyright: (C) 2021 by the author. Licensee MDPI, Basel, Switzerland. This article is an open access article distributed under the terms and conditions of the Creative Commons Attribution (CC BY) license (https:/ / creativecommons.org/licenses/by/ $4.0 /)$.
Department of Biblical and Religious Studies, Azusa Pacific University, Azusa, CA 97102, USA; boropeza@apu.edu

\begin{abstract}
A phenomenon noticeable in many of Paul's quotations of Scripture is the way that they do not follow the texts he cites verbatim. This prompts the question as to whether his audience would be competent enough to detect these differences. This study considers aspects such as text variations, memory, notetaking, and rhetorical argument as potential factors related to Paul's flexible use of Scripture in Romans. The study then probes whether Paul's audience, particularly believing gentiles in Rome, would have known Jewish Scripture well enough to evaluate Paul's use of Scripture. Through congregational longevity, plurality of audience, synagogue influence, and other factors, it is concluded that there is indeed competency among Paul's auditors, but there is no evidence suggesting that he is concerned about their reacting negatively to the elasticity of his quotations.
\end{abstract}

Keywords: use of Scripture; audience competency; Romans; apostle Paul; intertextuality; gentiles; Christian origins; memory/memorization

\section{Introduction}

Paul's letter to the Romans, as a number of scholars propose, provides an example of the gospel message he proclaimed on his missionary trips (Rom. 1.1, 15-17). ${ }^{1}$ If so, the apostle's gospel would seem to include many quotes and allusions to Jewish Scripture (the so-called "Old Testament"), ${ }^{2}$ and by far Romans contains more quotes from Scripture than any of his other letters (see below). The number rises significantly if allusions are included. ${ }^{3}$ No doubt, the apostle's study of Scripture did not end after his formal training as a Pharisee when he excelled in Jewish traditions that almost certainly included the study of the Torah (Gal. 1.13-16). His encounter with Christ on the way to Damascus would seem to have compelled him to revisit Scripture and interpret it in light of his new experience and calling to reach gentiles.

Since he considered Scripture to be the "oracles of God" (Rom. 3.2), its content would be continually alive and relevant for him. With the guidance of God's Spirit, his further readings and reflections could prompt him to reshape portions of his messages, emphasize different aspects of his gospel, and link and blend Scripture texts together in order to come up with fresh ideas aimed at helping persuade his audiences more thoroughly. As Wagner (2014, p. 154) rightly affirms, "Scripture not only testifies to Paul's gospel: it also enables Paul to understand that gospel more deeply and to articulate it more forcefully".

Conversely, if Paul's aim was to persuade audiences to follow Jesus as Lord, a deliberate misreading of Scripture might undermine that aim, even if detected by just a few informed listeners. The negative impact of Scripture perceived as being used wrongly seems clear enough to Paul and his congregations, if the problem in Galatians over the law is an example (Gal. 2-4; see also 2 Cor. 11.4; cf. 2 Tim. 2.23-26; Acts 17.11). It would seem to be the case, then, that Paul could not afford to underestimate his audience's knowledge of Scripture and potential to learn from it.

With these preliminary thoughts in place, one may wonder why Paul seems to be almost cavalier in his attitude towards Scripture quotes that frequently do not follow a 
verbatim reading of the sources he cites. Katja Kujanpää's recent and thorough examination of the apostle's quotations in Romans reveals that of the 64 quotes examined, only 21 are verbatim with the text they intend to cite (Kujanpää 2019). ${ }^{4}$ One wonders also about his audience's competency with Scripture. Would they be able to detect this lack of one-to-one correspondence? If the church in Rome consisted of gentiles (Rom. 1.5-6; 11.13), they may not have been schooled in Jewish texts and traditions. For Jews, on the other hand, it was expected that children go to school and learn the Torah (y. Ket. 8.32c; see similarly T. Lev. 13.2; Philo Leg. Gai. 210; Josephus Ap. 2.178)..$^{5}$ Fisk (2008, pp. 179-80) is probably right when affirming that the level of literacy may have been higher among synagogue attenders than the rest of society (cf. Josephus Ap. 2.204; Ant. 4.211; 4 Macc. 18.9-19; Hengel 1974, vol. 1, pp. 78-83). However, a number of gentile congregation members did not have such an upbringing and would likely be ignorant of the Torah. Likewise, many may have been illiterate as were many people in the ancient world, especially among the lower social classes. ${ }^{6}$ So then, who might have been competent enough to notice any misquotes of Scripture?

Questions about audience competency are important ones for biblical scholarship. The Society of Biblical Literature seminar "Paul and Scripture" investigated this very point among others (Stanley 2008, pp. 3-10). At the end of a six-year study, the seminar concluded broadly that although the majority of Pauline audiences were illiterate, there was no agreement among investigators on what implications might arise from this (Stanley 2012, pp. 321-30). Paul's use of Scripture and his audience's capabilities regarding it, then, need to receive further attention, and this study responds to that awareness.

\section{Flexibility and Paul's Use of Scripture}

We already mentioned that Paul's quotes in Romans often do not reflect a perfect replication of the text cited. As an example, in Rom. 2.24, he cites Scripture with his common verbal marker "just as it is written," but when we compare his quote with the text he cites from Isa. 52.5, the verse does not follow his wording:

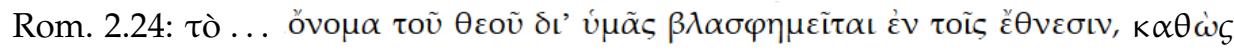
$\gamma \varepsilon ́ \gamma \rho \alpha \pi \tau \alpha \iota$

Isa. 52.5 MT: ותמיד כל־היום שמי מנאץ

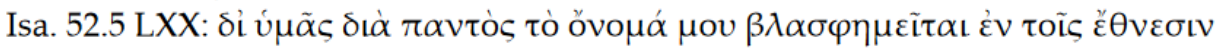

Both Paul and LXX Isaiah differ from the Hebrew text by adding the phrases $\delta \imath^{\prime} \quad \dot{\mu} \mu \tilde{\alpha} \varsigma$

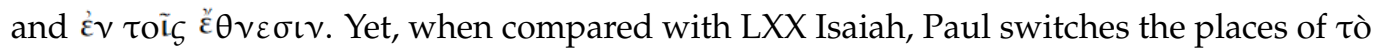

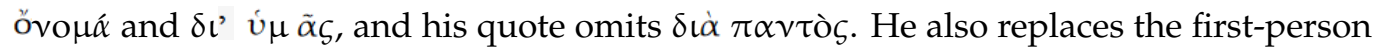

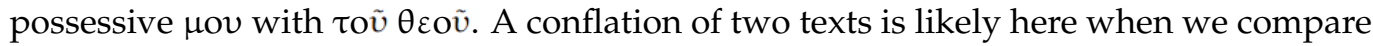
Isa. 52.5 with Ezek. 36.20-23. Such conflations, as well as the midrashic technique of linking texts together by virtue of the same or similar catch words, might help solve some comparative perplexities; however, in this case Paul's differences with Ezek. 36.20-23 are even more noticeable (Oropeza 2021b). The switch in word order and use of different pronouns remain hard to explain if relying on a conflation or on midrashic devices. No doubt, these are useful to recognize when examining Paul's quotations in general, but we must look elsewhere for a more comprehensive explanation regarding the differences. Some other ideas that may help give account of Paul's alterations are as follows.

\subsection{Textual Variants}

It is possible that Paul is using a different variant of the texts he quotes than what is found in the LXX and MT. He may have been well aware of variant text readings, as were some of his near contemporaries, Josephus and the Qumran community (Norton 2011). Textual variants, especially in the LXX, are nothing new, and yet sometimes contemporary interpreters forget that copyist errors were not only a problem in Late Antiquity and the Middle Ages but also in the first century when Paul wrote his letters. It is implausible to suggest that ancient written texts would be exactly alike without any variations (see Stanley 1992, pp. 345-48, 354-55). Often the ancient reader would be left at the mercy 
of the scroll available, and sometimes this reader might be forced to choose between variants if fortunate enough to possess more than one scroll of the same text; that is, if that text happened to be unalike when comparing the scrolls. This explanation becomes all the more plausible for Paul's differences whenever we find an actual extant variant in Old Greek. When no such variant exists, however, this explanation becomes little more than guesswork.

\subsection{Memory Lapse and the Scarcity of Scripture Collections}

The unavailability of copies of scrolls or the impractically of possessing and consulting them whenever Paul wrote his letters, or both, may have factored into his citation liberties. Are we to assume that the apostle had a collection of Scripture scrolls that he took with him on perilous missionary trips? ${ }^{7}$ Even if we answer this in the affirmative, the amount of scrolls would seem to be very limited. Perhaps he had access sometimes to local synagogues and wealthy patrons who possessed scrolls or parchments that he could read. There is good evidence to suggest that the synagogues of his day possessed and read from the Scriptures (2 Cor. 3.14; Acts 13.15-16; 15.21; cf. Neh 8.8; Luke 4.15-28; 1QS 6.6-8; Josephus, Bell. 2.291; Ap. 2.175; Philo, Vit. Mos. 2.216). ${ }^{8}$ Unless we assume that Paul was kicked out of every synagogue the first time he visited, we could surmise that he had chances to read Scripture in some of them. Paul's own congregations probably had access to some writings given his stress on the importance of teaching, knowledge, and reading (e.g., 1 Cor. 12.8, 28; 14.6, 26; 1 Thess. 5.27; cf. Eph 4:11; Col. 4.16). ${ }^{9}$ The congregations, similar to later ones in Deutero-Pauline literature, likely patterned their gatherings in a way similar to the synagogues by the public reading of Scripture (1 Tim. 4.13; 2 Tim. 3.15; 4.13; cf. Acts 17.11).

Even so, while it may be plausible to suggest that Paul had access to certain scrolls in the cities he visited, this is still not the same thing as his possessing a complete "canonical" collection readily available at his fingertips whenever he wrote his letters. All this is to say that many times when preaching and writing, it is quite possible that Paul had to quote from memory. This procedure was encouraged or assumed in both Greco-Roman and Jewish traditions (Rhet. Her. 3.16.28; Cicero, Orat. 1.18; Quintilian Inst. 11.2.1, 3; 2 Macc 2.25). ${ }^{10}$ The Pharisees passed on oral traditions (Josephus Ant. 13.297, 408; Mark 7.3, 8-9), boys were to memorize and learn the Torah (Josephus Vit. 8-12; $m$. 'Abot 5.21A), and Jews delighted in memorizing Jewish historical details (2 Macc 2.24-25; Keener 2019, p. 430). Vorster adds that:

"As a result of the interpretation of the Torah by the Pharisees and the fact that the Jews of that time applied themselves to memorise, transmit and repeat it, an oral Torah soon originated besides the written Torah. This oral Torah consisted of contemporary interpretation and application of the written Torah. Eventually, a mass of pronouncements originated with the aid of which the Jews could organise and arrange their lives. These pronouncements were repeated, memorised and transmitted by persons who studied the teachings of their teachers of [sic] by heart in an advanced training centre, the so called Beth Midrash (Hebr. bèt hammidrās ${ }^{\iota}=$ the house of study)" ${ }^{11}$ It is quite plausible that Paul as a former Pharisee would have memorized portions of Scripture and perhaps even certain early interpretations of it.

Certain word differences, then, would be the natural outcome of Paul's imperfect recollection or gist memory (McIver 2017). Jocelyn Small's study on memory and literacy in the ancient world affirms that when classical authors quoted a text, they often did not check for accuracy due to the logistical problems of consulting the actual source. They also had confidence in the excellence of their memories and a lack of concern to make their quotes verbatim with the original sources (Small 1997, pp. 219-20). Their citations thus resulted in such blunders as using the wrong words (Aristotle, Rhetorica 3.IX.7.1410a/Isocrates Panegyrics 1, 35, 41, 72, etc.), referencing the wrong speaker (Cicero, De Divinatione 2.XXX.63/Homer Il. 2.278-99), and referencing the wrong work (Aristophanes, Ranae 1124-28/ attributing Agamemnon to the Choephoroi; Small 1997, p. 318). It may be reductionistic, however, to blame bad memory on all or many of Paul's quote 
variations. At least some changes appear to be deliberate, such as his alteration of $\mu \mathrm{v}$ to $\theta \varepsilon o \tilde{v}$ in Rom. 2.24.

\subsection{Notetaking}

Notetaking and the possession of notebooks with Scripture references are other possible reasons for the apostle's variants (see examples in Pliny Ep. 3.5.17; Athenaeus Deip, 8.336d; Plutarch Mor. 464F; cf. 4QTest; 4Q177; Wagner 2003, pp. 20-28; Stanley 1992, pp. 74-76; Small 1997, pp. 177-90). Paul may have copied portions of texts from local synagogues. Similarly, some suggest his possession of "testimonia," excerpted lists of Scripture quotes, whether from other apostles or Jewish sources (Albl 1999). ${ }^{12}$ These options by themselves, however, still seem to be insufficient for explaining all the complex ways Paul works with Scripture. ${ }^{13}$

\subsection{Rhetorical Argumentation}

Paul doubtless believed his quotes, and the way he quoted, would enhance rather than hinder his rhetoric. His quote in Rom. 2.24, for example, stands in the middle of a diatribe with an interlocutor who happens to be a Jewish teacher whose external observances of the law cannot hide his violations of it. ${ }^{14}$ Paul's quote in this dialog makes splendid rhetorical sense, even if his words do not reduplicate the text verbatim. His aim to persuade congregations makes it probable that he would alter the Scripture version he knew for the sake of his arguments and rhetoric. Christopher Stanley (1992, p. 264) seems correct in suggesting that Paul does not attempt to conceal from auditors "the fact that he had incorporated interpretative elements into the wording of his quotations ... Two passages are particular revealing. In Rom. 10:11, Paul quotes Isa 28:16 in a form different from that which he had used only twelve verses earlier in Rom. 9:33. In 1 Cor. 15:27, the shift is even more explicit: the verb is changed from Aorist to Perfect tense within the very same verse." Stanley's survey of Greco-Roman and ancient Jewish literature reveals a pattern similar to Paul's of omitting words, adding words, changing grammar, conflations, and changes of wording or word order (Stanley 1992, pp. 343-45, 349-50).

\subsection{Combination of Factors}

It is perhaps best not to limit any of the possibilities above as the panacea for Paul's quote variations. A combination of factors is probably involved. ${ }^{15}$

Ancient authors like Paul do not seem as concerned about the flexibility of their quotes, to the frustration of certain biblical interpreters today who would like them to be a little less flexible. The apostle also does not appear to be citing texts in a manner unacceptable to his contemporaries. Norton (2011, pp. 47-56, 132-77, 178-81), who identifies in Paul's quotes "sense contours" which are "distinct semantic properties of alternative forms of the same passage," argues persuasively that Paul is familiar with textual plurality but not in an anachronistic sense of text types. Lexical fidelity is only "incidental to his engagement with the semantic currency of a given exegetical conversation" (Norton, p. 178). The apostle generally seems to be concerned about drawing in the semantic import of the Scripture necessary to make or support his argument, and he is not as concerned about getting the pronouns, tenses, and wording exactly right.

\section{Audience Competency in Romans}

Would Paul's audience know enough about the Scriptures he cites to notice his differentiations, and were they competent enough to have meaningful agreement and disagreement with his use of Scripture? The inundation of quotes in Romans may be suggestive of the audience's knowledge of Scripture. Depending on conflations and other factors, anywhere from 52 to about 64 quotes occur in this letter, whereas, among Paul's undisputed writings, 1 Corinthians stands at a distant second place with 14 quotes, 11 quotes appear in 2 Corinthians, and 10 in Galatians (see Wagner 2014, pp. 155-57 for a convenient list). If the Roman audience were new to the Scriptures, we might expect this letter to be compara- 
ble with his Thessalonian correspondence, where Scripture quotes are altogether missing (though allusions are present: see Öhler 2019), and Paul happens to be writing to a very young congregation comprised predominately of gentiles who were former idolaters (1 Thess. 1.9).

To be sure, excessive quoting may signal such things as Paul establishing his authority, or challenging his opponents' use of Scripture, or rhetorically ornamenting his discourse, or making, supporting, or amplifying his arguments. In 2 Corinthians, for instance, virtually all of these points are evident. Paul's authority is seriously questioned, his oratory skills are being challenged, and his opponents are influencing the congregation (Oropeza 2016). In this letter his authority needed to be defended, his words eloquent, and his arguments robust and convincing. Yet even in 2 Corinthians the amount of Scripture he cites per length of the letter does not begin to compare with the amount of quotes in Romans, where it is highly questionable that opponents or congregation members are even coming against his teachings and authority. ${ }^{16}$ These explanations, then, are not satisfying as alternatives to the more obvious reason for the surplus of quotes in Romans: Paul assumes his auditors in Romans know Jewish Scripture. A couple of examples will suffice to confirm this. In Romans 9.7-9 Paul distinguishes Isaac as Abraham's promised son among the patriarch's children in Genesis without even mentioning Ishmael as the competing son or Hagar as the competing mother against Sarah. He assumes his auditors already know the narrative. Again in 9.17-18, when quoting Exodus, Paul assumes his auditors will know that God hardened Pharaoh's heart without actually saying this.

This raises another question. If the Roman church is comprised of gentiles or mostly gentiles (cf. Rom. 1.5-6 13-15, 11:13), why does the apostle seem to have such a high estimation of his auditors' knowledge of Scripture? I provide several reasons below. The first of these deals more with dispelling assumptions about gentile capabilities than providing an actual reason.

\subsection{Gentiles and Scripture Competency}

Scholarly expectations that gentile followers of Christ were typically illiterate and ignorant of Scripture (e.g., Stanley 2004) are in need of qualifications. Ancient artifacts do not sufficiently evince that literacy in Paul's world could be reduced only to pagan elitists and Torah-fervent Jews. The working classes, prostitutes, and Roman soldiers along with the women connected with them all show signs of various degrees of literacy according to such findings as the Vindolanda tablets and ancient graffiti uncovered in places like Pompeii (Longenecker 2020, pp. 143-50; Poirier 2016; Holland 2016; Keegan 2015; Milnor 2014; Bagnall 2011; Bowman 1994). It will not suffice anymore to claim that the masses were entirely illiterate, nor that a person's non-elite status meant that such a person could not read (Gamble 2000, pp. 644-48). Moreover, one may question whether being a Christ-following gentile and illiterate should mean that such a person must remain relatively ignorant of Jewish Scripture given the prominence of oral memory and learning in the ancient world (Wagner 2003, p. 37; Abasciano 2007, pp. 153-83).$^{17}$ Former pagans of this sort would be able to attain certain levels of competency regarding Jewish Scripture if routinely hearing the word read aloud at the gatherings, a pattern which we already suggested as the norm for such meetings based on evidence from the New Testament. To reinforce such learning, the gatherings likely re-read Scripture and letters pertaining to Scripture multiple times, if not also including time for discussion about the Scriptures. As well, and akin with synagogue worship, hymns and psalms seem to have been sung at these meetings, which doubtless aided the memorization of lines from Scripture (1 Cor 14:26; Col 3:16; Eph 5:19; cf. Mark 14:26; Philo Contempl. 80; 1QH; b. Meg. 32a; Carey 2020). We should not assume, then, that simply because the Roman congregation is said to be gentile, this would disqualify them from knowing Scripture well. 


\subsection{Jewish Influence}

An important factor related to the Roman congregation's scriptural capacity was its association with Jews. Bruce Fisk (2008, pp. 157-85) is persuasive when affirming that the congregation originated from synagogues in which the reading of Scripture was quite prevalent. Fisk's perception of the recipients' knowledge correlates well with what we know about the socio-historical setting behind a number of first-century churches. ${ }^{18}$ Roman Christ followers may have originated in a manner characteristic of the book of Acts-from the synagogues (e.g., Acts 9.2, 20; 13.5, 14-48; 14.1; 17.1-4, 10-12, 16-17; 18.1-8, 19-21; etc.). If so, then one could surmise that the Roman church's first followers included Jews, gentile proselytes, and pagans with various degrees of commitment to the God of the Jews. ${ }^{19}$ Fisk suggests, among other things, the inclusion of decentralized synagogues in the city that may have differed in their openness to Christ's followers as well as gentiles attracted to ancient Judaism. He concludes that:

"It is precarious to make claims based solely on evidence within Romans about the competence of Paul's actual first readers. In light of what other sources tell us about synagogue practice, however, and given the lack of evidence that Rome's Christian community had uniformly severed its ties with the synagogue, it does not appear unreasonable to think that many of those who first read or heard Paul's letter would have enjoyed considerable prior, and ongoing, exposure to a number of the scriptural passages Paul cites". (p. 184)

Whether some of these gentiles were still exposed to the synagogues when Paul writes to them is a matter of debate, but the perspective that some of the Christ gatherings in Rome had been influenced by Jewish communities well-versed in Scripture is entirely plausible. Compatible with this view is Ambrosiaster (4th c. CE) who in the prologue of his ancient commentary on Romans claims that Jews in Rome who believed in Christ passed on their belief to the Romans. ${ }^{20}$ If so, then it is not at all unreasonable to assume that some of these gentiles may have become well-versed in Scripture.

\subsection{Paul's Prior Knowledge of the Romans}

Another reason why Paul may have aimed high regarding the congregation's Scripture knowledge was that, unlike recipients of his other letters, he had never visited this congregation. They were not the product of his missionary work (Rom 1.8-13). As such, he probably thought it prudent to present his gospel persuasively and attempt to establish respect among them by using Scripture generously while at the same time not underestimating their knowledge of it. Otherwise, the hope of this congregation assisting him on a future mission to Spain would be jeopardized (15.22-24). It could be surmised, then, that he writes as though his audience is already proficient in the Scriptures without knowing if this is actually the case. However, some of Paul's friends and colleagues knew the Romans according to Rom. $16,{ }^{21}$ and it could hardly be the case that he would never have asked them about the level of maturity of the church members. His inquiries very likely included questions regarding their knowledge about faith, Mosaic law, and the Scriptures. He claims to know already their reputation of faith, their members as predominantly gentiles, their material ability to support his missions, and presumably their susceptibility to divisions over table fellowship $(1.8 ; 14.1-15.6,22-24)$. He also assumes that some of them know the Torah well $(7.1,6)$. Why does he assume these things? His companions must have informed him. We have good reason to suspect, then, that even if he erred on the side of overestimating this congregation's competency in Scripture, he was not actually far off the mark.

\subsection{Longevity of the Congregation}

An issue routinely overlooked by biblical scholars is that the Roman congregation is not relatively new when Paul writes to them, unlike his own congregations. Roman believers in Christ had existed long enough to gain a reputation among the churches for 
their faith, and the congregation was stable enough to support Paul's future missions. Paul also tells these believers that he wanted to visit them "many times" in the past (1.13 cf. vv. 8-10). The congregation's longevity finds secondary support in Acts 2.10-11. If the narrative has any historical value (and I along with others believe it does) ${ }^{22}$ it shows that visitors from Rome were among the hearers of the earliest apostolic preaching in Jerusalem. Visitors to or from Rome may have also encountered Hellenistic Christ followers through the synagogue of the $\lambda_{\iota} \beta \varepsilon \rho \tau i v o l$ (Acts 6.9), the freed slaves of Romans. Keener (2:1303) suggests that people "regularly moved to and from Rome (cf. Rom. 16:3-15)," and he supports that immigration took place from Palestine to Rome (e.g., Josephus Vit. 13; CIJ 1:282.362; 1:287-88.370). Dunn (1988, p. xlvii) plausibly affirms that, "Through such contacts and the normal travel of merchants and others to the imperial capital, the new faith would almost certainly be talked of in the synagogues of Rome within a few years of the beginnings in Jerusalem, and groups would have emerged within these synagogues who professed allegiance to this form of eschatological Judaism".

Such encounters are suggestive of how the gospel pollenated to Rome, perhaps even prior to Paul's Damascus experience just a few to several years into the 30's CE. At least two individuals among or engaging with the Roman congregants, Andronicus and Junia, had been believers in Christ even prior to Paul (Rom. 16.7). We could entertain the possibility that-even apart from proselytes and god-fearers ${ }^{23}$ who had come to faith many years before Paul wrote this letter-if some former idolaters in Rome had turned to Christ back in the 30's CE, this would mean that they had been believers for 20 years or more by the time Paul writes this letter (c. 57-58 CE). Would they not have developed by now a proficiency in their faith and the Scriptures after many years of routinely hearing and discussing Scripture at their gatherings? It is evident that a teaching ministry comparable to Pauline churches was already established in Rome (Rom. 12.6-7; cf. 1 Cor. 12.28-29; 14.26; Eph. 4.11; 1 Tim. 3.2; 2 Tim 2.2). This would allow for congregation members to gain further knowledge of Scripture as new and illiterate members could learn from the more competent and literate members. Paul could trust also that God's Spirit would be at work gifting teachers in the congregation to utilize their gifts to assist others when interpreting Holy Scripture. That same Spirit, he believed, prompted him to teach what he did from the Scriptures and fortified him with confidence that his inspired messages would make a positive impact on Spirit-led hearers.

Interestingly, Hebrews, a letter possibly from Rome (Heb. 13.24), rivals Romans when it comes to Scripture references. The congregation addressed in it had existed for a long time and heard the word of God frequently (Heb. 2.1-4). Another example of how a congregation's longevity may assist in Scripture knowledge is evident with the Corinthians. The group originally consisted of pagans who turned to Christ (1 Cor. 12.2), but they had become competent in Scripture in the decades that followed their founding in the 50's CE. When Clement writes to them (c. 90's CE) and quotes the Psalms and Law to them, he says of this congregation, "For you know, and know well, the Holy Scriptures" (1 Clem. 53.1:

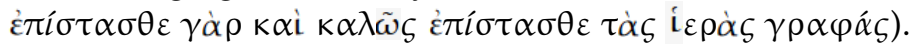

This perspective supports the notion that an author's repetitive citations from Scripture reflects an audience mature and competent enough to appreciate those citations, even if that audience is primarily gentile. This appears to be the case with the Romans. Paul could affirm them as being "filled with all knowledge" and "able to instruct one another" (Rom 15.14).

\subsection{Multiple Auditors}

Finally, in Romans, Paul is not addressing his message merely to a gentile group. In terms of the actual audience, it comes as no surprise that a majority of scholars and commentators affirm that a minority of Jewish believers grace this predominantly gentile congregation. Although scholars such as Stowers (1994) argue for a gentile audience only, Romans 16 becomes a difficult obstacle for this view since nine names appear to be Jewish and are associated with the greetings related to Rome (Schnabel 2015, vol. 2, p. 869). 
Although it has been argued that these individuals are missionaries (Das 2007, p. 101), Moo (2018, vol. 11, p. 934) speaks on behalf of many scholars that regard these Jews as actual members of the Roman congregation. I would suggest they are a combination of both members and missionaries, and this still means that some Jewish members belong to the Roman congregation. They doubtless knew the Scriptures well, which would be one more reason why Paul quotes Scripture so often in this letter.

\subsubsection{Stowers' Three Readers}

Stanley Stowers (1994, pp. 21-22) distinguishes between three readers in Romans. The first is the empirical reader who was actually at the event of the reading of this letter in Rome. For me, this group would seem to include a minority of Jews in this congregation, as already stated. Even Stowers does not deny Jewish members at this level (Stowers 1994, p. 33). The second reader for Stowers is the encoded explicit reader. This is the audience in the text to whom Paul makes explicit reference, such as when he uses direct address, second and first-person plurals, and calls them "gentiles" (Rom. 1.5-6, 13; 11.13). The third type is the encoded implicit reader, who is the ideal reader for whom assumptions, knowledge, and expectations in Romans are implicitly supposed to be understood. Such a person understands Jewish Scripture, some things about Jewish law, Jewish and Greco-Roman cultural codes, rhetorical conventions, and beliefs regarding Christ and God.

Stowers makes a strong distinction between the empirical and encoded readers in an effort to argue for a gentile audience rather than a Jewish Christian one: the encoded readers are gentiles. However, there are some problems with these distinctions. One setback is that Stowers has to admit an encoded explicit Jew appears in Rom. 2.17-29. He claims that the problem here rests with this person's attempt at getting gentiles to conform to the works of the law, which stands in antithesis to Paul's gospel (Stowers 1994, pp. 150-53). The focus of this passage for Stowers, then, remains on gentiles. However, the more overt problem in this text centers on this person's own violation of the Torah and hypocrisy as a teacher of the Torah, which then centers on proper and improper moral behavior in relation to being Jewish (Oropeza 2021a). Another setback for Stowers is that empirical and encoded readers can overlap, and if so, this does not necessarily do away with the minority of the empirical Jewish readers evident in Romans 16. It is not at all unlikely that some of these Jews have been involved in teaching the gentile members, which is another formidable reason why Paul does not underestimate the gentile members' knowledge of Scripture.

Nevertheless, one of the merits of Stowers' view relevant for our study is the way he distinguishes between three types of readers. I concur that all three of these types can be derived from the text, even though I would not propose such a wide gap between the empirical and encoded readers as Stowers appears to make. I would also suggest that in ancient congregational settings the majority of empirical "readers" are better described as "auditors" since they listen to the letter being read out loud by only one reader. I thus prefer to use to term "auditor" rather than "reader." In addition, differently than Stowers, I consider there to be at least two other types of auditors: rhetorically explicit auditors and rhetorically implicit auditors. ${ }^{24}$ I regard these as rhetorical because they are constructed from Paul's arguments in the letter as well as from his attempts to persuade those who listened to his oral performances.

\subsubsection{Rhetorically Explicit Auditors}

The rhetorically explicit auditors include the argumentative interlocutors whom Paul constructs in his diatribe in Romans. In Rom. 2:17-29 this auditor happens to be a Jewish teacher of the Torah. ${ }^{25}$ There may be more of these auditors if, for example, other interlocutors such as the one called "o man" ( $\left.\tilde{\omega} \alpha{ }^{\prime} v \theta \rho \omega \pi \varepsilon\right)$ in Rom 2:1 and 9:20 imagines a different person than the Torah teacher. In any case, the Torah teacher happens to be just as competent with the Scriptures as Paul (2.17-21a). We could surmise that Paul's 
use of Scripture assumes that at least a portion of his interlocutors know the Jewish texts extremely well.

\subsubsection{Rhetorically Implicit Auditors}

Since Paul's message in Romans is a variation of the gospel he proclaimed in different cities (1.15-16; 15.15-16), it includes another audience: rhetorically implicit auditors. These people represent the imagined Jews and gentiles who hear Paul's proclamations in the marketplaces, town halls, and synagogues that he visited when travelling. It is also not far-fetched to suggest that he wrote a good portion of the letter as a dry run either for what he planned to preach in Jerusalem once he arrived, or what he planned to proclaim in public spaces once in Rome (Rom. 15.25-31). The presence of this audience provides yet one more reason why Paul aimed so high regarding his use of Scripture: Jews from the synagogue are envisioned among his hearers. From what can be adduced in the letter, this auditor perhaps overlaps much with the encoded implied reader of Stowers. In my view, however, the rhetorically implicit auditor is foregrounded in the earlier chapters of Romans, whereas the encoded implied reader comes to the foreground towards the end of Romans (e.g., chps. 12-15). That is because a shift takes place from Paul's proclamation of the gospel imagined in public spaces in the earlier chapters, to Paul's exhortational material in later chapters that is more relevant in the private spaces of household settings where believers in Christ meet to be discipled and encouraged.

As Hays (2005, p. 49) rightly recognizes regarding Paul and his auditors, they are "at least as sophisticated and nuanced in their reading of Scripture as we are. Everything about Paul's use of OT texts suggests that his 'implied reader' not only knows Scripture but also appreciates allusive subtlety." The "real" reader, however, may not have attained the level of the implied reader, and so distinctions between such auditors remain important (White 2017, p. 176). All the same, we have already established above that even the real reader-the predominantly gentile audience in Rome who first heard Paul's letter read to them-has adequate competency with regard to Scripture.

\section{Competency and Scripture Use}

Given that being a gentile in first-century Christ congregations does not necessarily mean that such a person is illiterate, and that being illiterate does not necessitate incompetency regarding Scripture, along with reasons such as the longevity of the Roman congregation, the members' association with Jews, and Paul's ability to learn about their competency through his friends in Rome (some of them Jews), I affirm that Paul thought a number of the congregation members were competent regarding the Scriptures. Moreover, this number increases when we add the various types of auditors imagined from the text.

We are now diving deeper into the arena of conjecture and admit this in all humility, but we must pose the question: given Paul's assumptions about the Romans' competency, would he assume that his auditors might recognize his alterations of the wording and content related to his Scripture quotations? All I can say is that, if he did, there is no evidence suggesting that he is worried about it. Even his interlocutors do not object to his Scripture alterations when responding to his arguments from Scripture. They rather contest the way he interprets the text to support his argument. The interlocutor in Rom. 9.10-19, for instance, objects to the seemingly unjust and arbitrary way election and divine hardening take place through Paul's use of Scripture. However, this same objector does not fault him for taking Jacob and Esau in Mal. 1.2-3 out of context or for altering "on

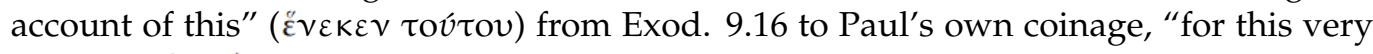

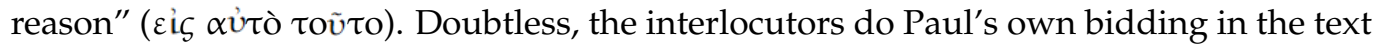
as their inventor, but it is very likely that such objections originated on the mission field from actual opponents Paul encountered when proclaiming and teaching his gospel (notice especially Rom. 3.1-8). Did those actual opponents also contest such things as Paul's wording from Scripture and possibly taking things out of context? If so, Paul does not reveal this information to his letter audience. He seems to be satisfied with how he uses 
the semantic import of the Scriptures he quotes, and he apparently assumes his audience will likewise be satisfied.

\section{Conclusions}

The various issues we covered point in the direction that Paul had more than one type of audience in view when writing his gospel in this letter, and he likely anticipated that a number of his listeners would be competent when it comes to Scripture knowledge. They seemed well informed due to such things as the congregation's level of maturity and longevity, Jewish influence, and his knowing something about the congregation's knowledge beforehand. As with other gospel messages proclaimed to mixed audiences, he could also expect that the informed members would likely teach the uninformed members regarding the Scriptures. His elastic use of Scripture does not appear to be a crux issue in the letter. He, along with other ancient writers, seemed to be accustomed to such quotation alterations; and he did not seem to be bothered by the possibility of his audience detecting those alterations.

Funding: This research received no external funding. However, the author would like to thank his university for permitting him the opportunity to attend the university's annual Writers's Retreat (headed by Dr. Donald Isaak); a draft of this article was written at the retreat.

Institutional Review Board Statement: Not applicable.

Informed Consent Statement: Not applicable.

Conflicts of Interest: The author declares no conflict of interest.

\section{Notes}

1 On the theme of the letter as the gospel, see, e.g., (Moo 2018, pp. 25-28; Longenecker 2016, pp. 16-18; Schnelle 2003, pp. 309-12; Stuhlmacher 1991, pp. 333-45); though of course the letter can have more than one theme and purpose. On various proposals, see, e.g., (Donfried 1991; Das 2007, pp. 24-52).

2 Paul's quotes mostly come from a Vorlage comparable with the LXX, though there are exceptions in which his text follows better the Hebrew (MT), and other times his quotes follow neither tradition. See a convenient list in (Silva 1993, p. 631). For an example of Hebrew use in Romans see Rom 9:17/Exod 9:26 (Abasciano 2012, pp. 155-67). As a young man I had memorized both biblical chapters and books from the KJV. Almost 40 years later when I cite a passage by memory (many times imperfectly!) or translate it from Greek, I have a tendency to default to wording I had memorized from the KJV many years ago. My suspicion is that Paul had memorized large portions of Scripture in Hebrew when growing up and/or studying as a Pharisee. If so, then our hypothesizing that Paul's version sometimes resembles the MT over LXX because the Greek translator of his text tried to get it to conform to the Hebrew text (e.g., Kujanpää 2019, p. 335) may not be necessarily accurate. Paul's version may sometimes resemble the Hebrew version because that is the way Paul memorized it even though knowing the LXX version (or memorizing it), too.

3 For quotations and potential allusions in Romans, see, e.g., (Hübner 1997, pp. 2-219), who has more than 200 pages worth. His list nonetheless does not exhaust all potential allusions.

4 Her summaries appear on pp. 60, 82, 130-31, 204-06, 263, 296, 330. My count includes conflated texts. She misses, however, Ezek. 36.20-23 that is conflated with Isa. 52.5 in Rom. 2.24.

5 The Palestinian Talmud in the first entry records a tradition going back to Simeon ben Shetach (c. 100 BCE). Its widespread enforcement, however, is not known (Millard 2000, pp. 157-58).

6 Stanley 2004 likewise raises this and similar concerns. On ancient literacy, the findings of Harris (1989), have been influential in biblical scholarship. Harris (323-32) claims a literacy rate in Greco-Roman cities on average as only 10 to $15 \%$. For a critique of this position, see (Hilton 2018, pp. 16-20).

7 Hickling (1978, pp. 215, 219-20), compares Paul travelling with scrolls with the eunuch in Acts 8.27-28 and posits that a scroll over 30 feet long and 9-10 inches high would fit into a cylinder about 1-1 $\frac{1}{2}$ inches in diameter. Notice also 2 Tim. 4.13.

8 See further (Hezser 2019, vol. 2, pp. 427-29; Lichtenberger 1996, pp. 22; Levine 1987, pp. 7-32; Petuchowski 1983, pp. 27-33). On synagogues and individuals owning Torah scrolls, see (Millard 2000, pp. 158-66).

9 Such congregations are also encouraged to circulate Paul's letters with whatever Scriptures in those letters he might have cited, but it stretches the imagination too thin to think that his letters were the only thing read at these gatherings.

10 See further (Galinsky 2014; Mackay 2008; Mendels 2004; Small 1997, pp. 178-80). On the importance of memorizing in early Jewish and Christian traditions, see (Smit 2016; Horsley 2013; Zvi and Levin 2012; Barton et al. 2007; Kirk and Thatcher 2005; Jaffee 2001). (Greenspoon 2012, pp. 10-18), lists 1 Cor 9.7, 9, and Rom. "11:2ff" as examples of Paul using memory. 
Vorster (1998, p. 1446[\$157.2]); italics were bold face in the original. See also (Yuval 2011).

12 Adams and Ehorn (2018, pp. 217-18), work with composite texts and rightly affirm that these texts can function like midrash to enhance hermeneutics from one text to the other. One shortcoming of this otherwise fine work is that the contributors do not focus on ancient midrash techniques. For an example of how Scripture texts were linked together via midrash and Hillel's gezara shava in Paul, see (Baron and Oropeza 2016; Stegner 1984).

13 Critical of testimonia, for example, is (Lincicum 2008, pp. 297-308). The importance of apostolic kerymatic tradition on Paul's hermeneutics, at any rate, should not be ignored: see (Bates 2012, pp. 56-57, 100-8).

This interlocutor calls himself (or is called) a Jew (Rom 2:17), but (Thorsteinsson 2003; Rodriguez and Thiessen 2016), and certain others argue that this person is really a gentile. For a response see (Oropeza 2021a).

15 Literary creations and oral memory are combined by, e.g., (Achtemeier 1990, pp. 3-27; Stanley 1992, pp. 350-51).

16 Neither Rom. 3.8 nor 16.17-18 insinuate that Roman congregation members are the present problem or had already bought into the teachings of Paul's opponents (cf. 1.8; 15.14-15). Against a situation revolving around opponents in Rome, see recently, (Foster 2016, chp. 3; Oropeza 2012, pp. 136-44).

17 See further the sources in note 10 .

18 Fisk (2008, pp. 159-60), who sets out to answer two questions: “What can we know about the historical relationship between church and synagogue in mid-first century Rome? And how much has the synagogue shaped, schooled, and influenced Paul's earliest Roman readers?".

19 Fisk (2008, pp. 166-72), argues that synagogues/houses of prayer ( $\pi \rho \circ \sigma \varepsilon v \chi \alpha \hat{\imath})$ date back to the time of Claudius or earlier in Rome: cf. Philo Legal. 155-57; hypogea inscriptions, Roman catacombs (Runesson 1999, pp. 409-33). In Epistolam ad Romanos, Prologus \$25 in J. P. Migne, Patrologiae (Series Prima) XVII, pp. 45-46.

On the authenticity of Romans 16, see (Das 2007, pp. 16-23; Wedderburn 1988, pp. 12-18).

The most comprehensive study on Acts in modern times (Keener 2012-2015) affirms its historicity as well. See also (Hemer 1990).

By god-fearers I mean here gentiles who honored the God of the Jews and adhered to Jewish ways though not completely (e.g., they remained uncircumcised). See Josephus Ant. 20.41; Joseph and Aseneth 27.1; 28.7; Acts 10:2, 22; 13:16 (McKnight 2000; Trebilco 1991, pp. 145-66).

I mentioned "at least" three auditors in Romans for another recent publication (Oropeza 2021-2022), which now enables me to expand here. I am not alone in thinking there are more than three. Various audiences were discussed recently in a Paul within Judaism session entitled, "Who is the Implied Audience of Paul's Letter to Rome?" (Society of Biblical Literature conference, Denver; 17 November 2018). Respondent panelist John M. G. Barclay, for example, distinguished actual, intended, declared, and implied readers.

Pace scholars who claim this is a gentile. See note 14 above.

\section{References}

Abasciano, Brian J. 2007. Diamonds in the Rough: A Reply to Christopher Stanley Concerning the Reader Competency of Paul's Original Audiences. NovT 49: 153-83. [CrossRef]

Abasciano, Brian J. 2012. Paul's Use of the Old Testament in Romans 9:10-18: An Intertextual and Theological Exegesis. LNTS 317. London: Bloomsbury.

Achtemeier, Paul. 1990. Omne verbum sonat: The New Testament and the Oral Environment of Late Antiquity. JBL 109: 3-27. [CrossRef]

Adams, Sean A., and Seith M. Ehorn, eds. 2018. Composite Citations in Antiquity: Volume Two: New Testament Use. LNTS 592. London: Bloomsbury.

Albl, Martin C. 1999. 'And Scripture Cannot be Broken': The Form and Function of the Early Christian Testimonia Collections. NovTSup 96. Leiden: Brill.

Bagnall, Roger S. 2011. Everyday Writing in the Graeco-Roman East. Sather Classical Lectures 69. Berkeley: University of California Press.

Baron, Lori, and B. J. Oropeza. 2016. Midrash. In Exploring Intertextuality: Diverse Strategies for New Testament Interpretation of Texts. Edited by B. J. Oropeza and Steve Moyise. Eugene: Cascade, pp. 63-80.

Barton, Stephen C., Loren T. Stuckenbruck, and Benjamin C. Wold, eds. 2007. Memory in the Bible and Antiquity: The Fifth DurhamTübingen Research Symposium. WUNT 212. Tübingen: Mohr-Siebeck.

Bates, Matthew W. 2012. The Hermeneutics of the Apostolic Proclamation: The Center of Paul's Method of Scriptural Interpretation. Waco: Baylor University Press.

Bowman, A. K. 1994. Life and Letters on the Roman Frontier. New York: Routledge.

Carey, Holly J. 2020. Psalm 22 in Mark's Gospel: Moving Forward. In New Studies in Textual Interplay. Edited by Craig A. Evans, B. J. Oropeza and Paul T. Sloan. SSEJC 20/ LNTS 632. Londong: Bloomsbury, pp. 121-37.

Das, A. Andrew. 2007. Solving the Romans Debate. Minneapolis: Fortress.

Donfried, Karl P., ed. 1991. The Romans Debate, Revised and Expanded Edition. Peabody: Hendrickson.

Dunn, James D. G. 1988. Romans 1-8. WBC 38A. Dallas: Word.

Fisk, Bruce N. 2008. Synagogue Influence and Scriptural Knowledge among the Christians of Rome. In As It Is Written: Studying Paul's Use of Scripture. Edited by Stanley E. Porter and Christopher D. Stanley. SBLSS 50. Atlanta: SBL Press, pp. 157-85. 
Foster, Robert B. 2016. Renaming Abraham's Children: Election, Ethnicity, and the Interpretation of Scripture in Romans 9. WUNT $2 / 421$. Tübingen: Mohr-Siebeck.

Galinsky, Karl, ed. 2014. Memoria Romana: Memory in Rome and Rome in Memory. Ann Arbor: University of Michigan Press.

Gamble, Harry Y. 2000. Literacy and Book Culture. In Dictionary of New Testament Background. Edited by Craig A. Evans and Stanley E. Porter. Downers Grove: InterVarsity, pp. 644-48.

Greenspoon, Leonard. 2012. By the Letter? Word for Word? Scriptural Citation in Paul. In Paul and Scripture: Extending the Conversation. Edited by Christopher D. Stanley. ECIL 9. Atlanta: SBL Press, pp. 9-24.

Harris, William V. 1989. Ancient Literacy. Cambridge: Harvard University Press.

Hays, Richard B. 2005. The Conversion of the Imagination: Paul as Interpreter of Israel's Scripture. Grand Rapids: Eerdmans.

Hemer, Colin J. 1990. The Book of Acts in the Setting of Hellenistic History. Edited by Conrad H. Gempf. Winona Lake: Eisenbrauns.

Hengel, Martin. 1974. Judaism and Hellenism: Studies in Their Encounter in Palestine during the Early Hellenistic Period. London: SCM, 2 vols.

Hezser, Catherine. 2019. Literacy and Reading. In T \& T Clark Encyclopedia of Second Temple Judaism. Edited by Daniel Gurtner and Loren T. Stuckenbruck. London: T \& T Clark, vol. 2, pp. 438-40.

Hickling, C. J. A. 1978. Paul's Reading of Isaiah. Studia Biblica 3: 215-23.

Hilton, Allen R. 2018. Illiterate Apostles: Uneducated Early Christians and the Literates Who Loved Them. LNTS 541. London: T. \& T. Clark.

Holland, Glenn S. 2016. Paul and Performance. In Paul in the Greco-Roman World, 2nd ed. Edited by J. Paul Sampley. London: T. \& T. Clark, pp. 239-69.

Horsley, Richard A. 2013. Text and Tradition in Performance and Writing. Biblical Performance Criticism 9. Eugene: Wipf \& Stock.

Hübner, Hans. 1997. Vetus Testamentum in Novo. Band 2 Corpus Paulinum. Göttingen: Vandenhoeck \& Ruprecht.

Jaffee, Martin F. 2001. Torah in the Mouth: Writing and Oral Traditions in Palestinian Judaism 200 BCE-400 CE. Oxford: Oxford University Press.

Keegan, Peter. 2015. Graffiti in Antiquity. London: Routledge.

Keener, Craig S. 2012-2015. Acts: An Exegetical Commentary. Grand Rapids: Baker Academic, 4 vols.

Keener, Craig S. 2019. Christobiography: Memory, History, and the Reliability of the Gospels. Grand Rapids: Eerdmans.

Kirk, Alan, and Tom Thatcher, eds. 2005. Memory, Tradition, and Text: Uses of the Past in Early Christianity. Leiden: Brill.

Kujanpää, Katja. 2019. The Rhetorical Functions of Scriptural Quotations in Romans: Paul's Argumentation by Quotations. NovTSup 172. Leiden: Brill.

Levine, Lee I. 1987. The Second Temple Synagogue: The Formative Years. In The Synagogue in Late Antiquity. Edited by Lee I. Levine. Philadelphia: American Schools of Oriental Research, pp. 7-32.

Lichtenberger, Hermann. 1996. The Understanding of the Torah in the Judaism of Paul's Day. In Paul and the Mosaic Law. Edited by James D. G. Dunn. Grand Rapids: Eerdmans, pp. 7-23.

Lincicum, David. 2008. Paul and the Testimonia: Quo Vademus? JETS 51: 297-308.

Longenecker, Richard N. 2016. The Epistle to the Romans. NIGTC. Grand Rapids: Eerdmans.

Longenecker, Bruce W. 2020. In Stone and Story: Early Christianity in the Roman World. Grand Rapids: Baker Academic.

Mackay, Anne, ed. 2008. Orality, Literacy, Memory in the Ancient Greek and Roman World. Leiden: Brill.

McIver, Robert K. 2017. Gist Memory. In The Dictionary of the Bible and Ancient Media. Edited by Tom Thatcher, Chris Keith, Raymond F. Person Jr. and Elsie R. Stern. London: Bloomsbury, pp. 156-57.

McKnight, Scot. 2000. Proselytism and Godfearers. In Dictionary of New Testament Background. Edited by Craig A. Evans and Stanley E. Porter. Downers Grove: InterVarsity Press, pp. 835-47.

Mendels, Doron. 2004. Memory in Jewish, Pagan and Christian Societies of the Graeco-Roman World. London: Bloomsbury.

Millard, Alan. 2000. Reading and Writing in the Time of Jesus. New York: New York University Press.

Milnor, Kristina. 2014. Graffiti and the Literary Landscape in Roman Pompeii. Oxford: Oxford University Press.

Moo, Douglas J. 2018. The Letter to the Romans, 2nd ed. NICNT. Grand Rapids: Eerdmans.

Norton, J. D. H. 2011. Contours in the Text: Textual Variation in the Writings of Paul, Josephus, and the Yahad. LNTS 430. London: Bloomsbury.

Öhler, Markus. 2019. Reception of the Old Testament in 1 Thessalonians and in Philippians? In Paul and Scripture. Edited by Stanley E. Porter and Christopher D. Land. Pauline Studies 10. Leiden: Brill, pp. 350-71.

Oropeza, B. J. 2012. Jews, Gentiles, and the Opponents of Paul: The Pauline Epistles. Apostasy in the New Testament Communities. Eugene: Cascade, vol. 2.

Oropeza, B. J. 2016. Exploring Second Corinthians: Death and Life, Hardship and Rivalry. RRA 3. Atlanta: SBL Press.

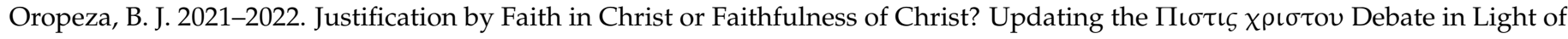
Paul's Use of Scripture. JTS 72.

Oropeza, B. J. 2021a. Is the Jew in Romans 2:17 Really a Gentile? Second Thoughts on a Recent Interpretation. Academia Letters 444: 1-4.

Oropeza, B. J. 2021b. Paul's Use of Deutero-Isaiah in Romans 2:24 and in the Gospel of Romans. In Scripture, Texts, and Tracings in Romans. Edited by Linda L. Belleville and A. Andrew Das. Lanham: Fortress Academic/Lexington Books, pp. 31-49.

Petuchowski, Jakob J. 1983. The Liturgy of the Synagogue: History, Structure, and Contents. In Approaches to Ancient Judaism, Volume IV: Studies in Liturgy, Exegesis, and Talmudic Narrative. Edited by William Scott Green. BJS 27. Chico: Scholars, pp. 1-64. 
Poirier, John C. 2016. Paul and Literacy. In Paul in the Greco-Roman World, 2nd ed. Edited by J. Paul Sampley. London: Bloomsbury/T. \& T. Clark, vol. 2, pp. 68-88.

Rodriguez, Rafael, and Matthew Thiessen, eds. 2016. The So-Called Jew in Paul's Letter to the Romans. Minneapolis: Fortress.

Runesson, Anders. 1999. The Oldest Original Synagogue Building in the Diaspora: A Response to L. Michael White. HTR 92: 409-33. [CrossRef]

Schnabel, Eckhard J. 2015. Der Brief des Paulus an die Römer. HTA Witten/Giessen: SCM R. Brockhaus/Brunnen, 2 vols.

Schnelle, Udo. 2003. Apostle Paul: His Life and Theology. Translated by M. Eugene Boring. Grand Rapids: Baker Academic.

Silva, Moisés. 1993. Old Testament in Paul. In Dictionary of Paul and His Letters. Edited by Gerald F. Hawthorne, Ralph P. Martin and Daniel G. Reid. Downers Grove: InterVarsity Press, pp. 630-42.

Small, Jocelyn Penny. 1997. Wax Tablets of the Mind: Cognitive Studies of Memory and Literacy in Classical Antiquity. London: Routledge.

Smit, Peter-Ben. 2016. Paul and Memory. In Paul in the Greco-Roman World, 2nd ed. Edited by J. Paul Sampley. London: T. \& T. Clark, vol. 2, pp. 147-70.

Stanley, Christopher D. 1992. Paul and the Language of Scripture. SNTSMS 74. Cambridge: Cambridge University Press.

Stanley, Christopher D. 2004. Arguing with Scripture: The Rhetoric of Quotations in the Letters of Paul. London: T. \& T. Clark.

Stanley, Christopher D. 2008. Paul and Scripture: Charting the Course. In As it is Written: Studying Paul's Use of Scripture. Edited by Stanley E. Porter and Christopher D. Stanley. Atlanta: SBL Press, pp. 3-10.

Stanley, Christopher D. 2012. What We Learned-What We Didn't. In Paul and Scripture: Extending the Conversation. Edited by Christopher D. Stanley. Atlanta: SBL Press, pp. 321-30.

Stegner, William Richard. 1984. Romans 9.6-29-A Midrash. JSNT 22: 37-52. [CrossRef]

Stowers, Stanley K. 1994. A Rereading of Romans: Justice, Jews, and Gentiles. New Haven: Yale University Press.

Stuhlmacher, Peter. 1991. The Theme of Romans. In The Romans Debate, Revised and Expanded Edition. Edited by Karl P. Donfried. Peabody: Hendrickson, pp. 333-45.

Thorsteinsson, Runar M. 2003. Paul's Interlocutor in Romans: Function and Identity in the Context of Ancient Epistolography. CB 40. Stockholm: Almqvist \& Wiksell.

Trebilco, Paul. 1991. Jewish Communities in Asia Minor. SNTMS 69. Cambridge: Cambridge University Press.

Vorster, W. S. 1998. The Jewish Literary Background of the New Testament: A Survey. In The New Testament Milieu. Edited by A. B. du Toit. Halfway House, Johannesburg: Orion Publishers, vol. 2, pp. 1290-472.

Wagner, J. Ross. 2003. Heralds of the Good News: Isaiah and Paul in Concert in the Letter to the Romans. Boston and Leiden: Brill Academic.

Wagner, J. Ross. 2014. Paul and Scripture. In The Blackwell Companion to Paul. Edited by Stephen Westerholm. Chichester: John Wiley \& Sons, pp. 154-71.

Wedderburn, A. J. M. 1988. The Reasons for Romans. Edinburgh: T. \& T. Clark.

White, Joel. 2017. Identifying Intertextual Exegesis in Paul: Methodological Considerations and a Test Case 1 Corinthians 6:5. In The Crucified Apostle: Essays on Peter and Paul. Edited by Todd A. Wilson and Paul R. House. WUNT 2/450. Tübingen: Mohr-Siebeck, pp. 167-88.

Yuval, Israel Jacob. 2011. The Orality of Early Jewish Law: From Pedagogy to Ideology. In Judaism, Christianity, and Islam in the Course of History: Exchange and Conflicts. Edited by Lother Gall and Dietmar Willoweit. Schriften des Historischen Kollegs 82. Munich: R. Oldenburg Verlag, pp. 237-60.

Zvi, Ehud Ben, and Christoph Levin, eds. 2012. Remembering and Forgetting in Early Second Temple Judah. FAT 85. Tübingen: Mohr-Siebeck. 